\title{
Design and Synthesis of Five Cyclobuta-1,3-Dien-1-yl- Steroid Derivatives to Evaluate Their Theoretical Activity Against COVID-19
}

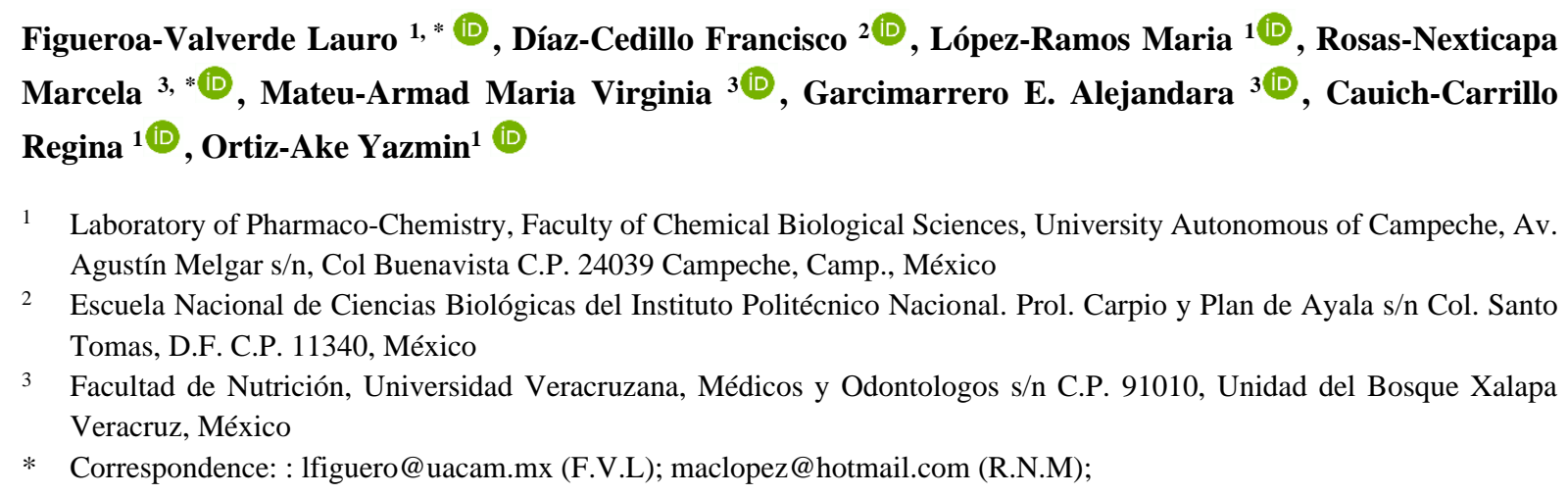

Received: 20.05.2020; Revised: 10.06.2020; Accepted: 12.06.2020; Published: 15.06.2020

\begin{abstract}
Several drugs have been prepared to evaluate their interaction with coronavirus disease (COVID-19) using some docking models. The aim of this research was to prepare five cyclobuta-1,3dien-1-yl-steroid derivatives from 3-ethylinaniline using some chemical reactions. In addition, the interaction of compounds 3 to 7 with COVID-19 (6LU7 protein) was evaluated using chloroquine, remdesivir, and favipiravir as controls in a theoretical model. The results showed that compounds 6 have a higher affinity by 6LU7-protein surface compared with either chloroquine, remdesivir, and favipiravir. In addition, remdesivir have lower affinity by 6LU7-protein in comparison with compound 5. In conclusion, this phenomenon suggests that either compounds $\mathbf{5}$ or $\mathbf{6}$ could exert some changes in the biological activity of COVID-19.
\end{abstract}

Keywords: Steroid; derivative; 3-ethylinaniline; COVID-19.

(C) 2020 by the authors. This article is an open-access article distributed under the terms and conditions of the Creative Commons Attribution (CC BY) license (https://creativecommons.org/licenses/by/4.0/).

\section{Introduction}

Respiratory diseases are one of the main health problems worldwide [1-6]. Some of these clinical pathologies have been related to severe acute respiratory syndrome coronavirus 2 (SARS-COV) [7-12]. It is noteworthy that some antiviral drugs have been used for the treatment of SARS-COV; unfortunately, at present, there is no drug to decrease respiratory diseases caused by SARS-COV. In search of some therapeutic alternatives, several compounds have been synthesized to the treatment of SARS-COV: For example, the synthesis of compound an oxohexanoic-acid analog from hydroxyhexanoic- acid derivative [13]. Furthermore, a report showed the synthesis of an oxo-pyrrolidin-3-yl)butanamide analog by the reaction of a $\alpha$-hydroxyamide with periodinane [14]. Other study shown the preparation of an indole derivative from 2,3-Dioxo-2,3-dihydro-1H-indole-5-carboxylic acid and 2(bromomethyl)naphthalene [15]. Additionally, a report indicated the synthesis of a carboxamide via reaction of pyridine-3-carboxaldehyde and 4-tert-butylaniline [16]. Other 
data, showed the synthesis of piperidine from of Naphthyl)ethyl]-4methoxycarbonylpiperidine and with dimethylformamide [17]. All these data have shown the synthesis of several drugs with activity against some SARS-CoV strains. However, the binding of these compounds with several SARS-CoV strains is very confusing; perhaps this phenomenon could be due to the different chemical structure of each compound. Analyzing these data, the objective of this investigation was to synthesize five cyclobuta-1,3-dien-1-ylsteroid derivatives to evaluate their theoretical activity against COVID-19 using the 6LU7protein as a theoretical model on the DockingServer.

\section{Materials and Methods}

\subsection{General methods.}

The steroid derivatives were prepared using a previous method reported [18, 19]. In addition, all reagents used in this investigation were acquired from Sigma-Aldrich Co., Ltd. The melting point for compounds was evaluated on an Electrothermal (900 model). Infrared spectra (IR) were evaluated with a Thermo Scientific iSOFT-IR spectrometer. ${ }^{1} \mathrm{H}$ and ${ }^{13} \mathrm{C}$ NMR spectra were recorded using a Varian VXR300/5 FT NMR spectrometer at $300 \mathrm{MHz}$ in $\mathrm{CDCl}_{3}$ using TMS as an internal standard. EIMS spectra were obtained with a Finnigan Trace Gas Chromatography Polaris Q-Spectrometer. Elementary analysis data were acquired from a Perkin Elmer Ser. II CHNS/02400 elemental analyzer.

\subsection{Synthesis of (3-Ethynyl-phenyl)-methyl-amine (2).}

In a round bottom flask $(10 \mathrm{ml}), 3$-ethynilaniline $(100 \mu \mathrm{l}, 0.90 \mathrm{mmol})$, potassium hydroxide $(50 \mathrm{mg}, 0.89 \mathrm{mmol})$, palladium on carbon $(100 \mathrm{mg}, 0.93 \mathrm{mmol})$ and $10 \mathrm{ml}$ of methanol were stirred at reflux for $12 \mathrm{~h}$. Then, the solvent was evaporated under reduced pressure and following the product was purified via crystallization using the methanol:hexane:water $(4: 2: 1)$ system; yielding $60 \%$ of product; m.p. $70-72{ }^{\circ} \mathrm{C}$; IR $\left(V_{\max }, \mathrm{cm}^{-}\right.$ 1) 3310 and 1602: ${ }^{1} \mathrm{H}$ NMR $\left(300 \mathrm{MHz}, \mathrm{CDCl}_{3}-d\right) \delta_{\mathrm{H}}: 2.82(\mathrm{~s}, 1 \mathrm{H}), 2.88(\mathrm{~s}, 3 \mathrm{H}), 4.82$ (broad, $1 \mathrm{H}), 6.54-7.12(\mathrm{~m}, 4 \mathrm{H}) \mathrm{ppm} .{ }^{13} \mathrm{C} \mathrm{NMR}\left(300 \mathrm{~Hz}, \mathrm{CDCl}_{3}\right) \delta \mathrm{c}: 30.32,78,22,84.00,114.50$, 122.12, 122.35, 126.22, 129.70, 151.30 ppm. EI-MS m/z: 131.07. Anal. Calcd. for $\mathrm{C}_{9}{ }_{9}{ }_{9} \mathrm{~N} . \mathrm{C}$, $82.41 ; \mathrm{H}, 6.92 ; \mathrm{N}, 10.68$. Found: C, 82.40; H, 6.90.

(13S,17S)-13-methyl-17-[4-[3-(methylamino)phenyl]cyclobuta-1,3-dien-1-yl]7,8,9,11,12,14,15,16-octahydro-6H-cyclopenta[a] phenanthrene-3,17-diol (3).

In a round bottom flask $(10 \mathrm{ml})$, compound 2 [100 $\mathrm{mg}, 0.76 \mathrm{mmol}], 17 \alpha-$ ethynilestradiol (fragment A) ([225 mg, $0.76 \mathrm{mmol}$ ], Copper(II) chloride [105 mg, $0.78 \mathrm{mmol}$ ] and $5 \mathrm{ml}$ of methanol were stirred at room temperature for $72 \mathrm{~h}$. Then, the solvent was evaporated under reduced pressure and following the product was purified via crystallization using the methanol:water (4:1) system; yielding $55 \%$ of product; m.p. $165-167{ }^{\circ} \mathrm{C}$; IR $\left(V_{\max }\right.$, $\left.\mathrm{cm}^{-1}\right) 3400$ and 3312: ${ }^{1} \mathrm{H}$ NMR $\left(300 \mathrm{MHz}, \mathrm{CDCl}_{3}-d\right) \delta_{\mathrm{H}}: 0.72(\mathrm{~s}, 3 \mathrm{H}), 1.12-2.50(\mathrm{~m}, 13 \mathrm{H}), 2.74$ $(\mathrm{s}, 3 \mathrm{H}), 2.77-2.80(\mathrm{~m}, 2 \mathrm{H}), 6.12(\mathrm{~d}, 1 \mathrm{H}, \mathrm{J}=-0.96 \mathrm{~Hz}), 6.26(\mathrm{broad}, 3 \mathrm{H}), 6.28(\mathrm{~d}, 1 \mathrm{H}, \mathrm{J}=-0.96$ $\mathrm{Hz}), 6.60(\mathrm{~m}, 1 \mathrm{H}), 6.72-6.76(\mathrm{~m}, 2 \mathrm{H}), 6.80-7.16(\mathrm{~m}, 2 \mathrm{H}), 7.20(\mathrm{~m}, 1 \mathrm{H}), 7.26(\mathrm{~m}, 1 \mathrm{H}) \mathrm{ppm} .{ }^{13} \mathrm{C}$ $\operatorname{NMR}\left(300 \mathrm{~Hz}, \mathrm{CDCl}_{3}\right) \delta_{\mathrm{C}}: 15.12,23.76,26.25,27.96,30.26,30.28,33.04,33.12,40.70,42.60$, 44.30, 50.88, 79.56, 112.54, 113.64, 115.96, 116.00, 119.55, 126.57, 126.76, 128.44, 128.60, 131.92, 135.66, 138.20, 138.50, 142.00, 146.06, 156.02 ppm. EI-MS m/z: 427.25. Anal. Calcd. for $\mathrm{C}_{29} \mathrm{H}_{33} \mathrm{NO}_{2}$. C, 81.46; H, 7.78; N, 3.28; O, 7.48. Found: C, 81.44; H, 7.73. 
(13S,17S)-13-methyl-17-[4-[3-(methylamino)phenyl]cyclobuta-1,3-dien-1-yl]-2-nitro7,8,9,11,12,14,15,16-octahydro-6H-cyclo-penta[a]phenanthrene-3,17-diol (4).

In a round bottom flask $(10 \mathrm{ml})$, compound 2 [100 $\mathrm{mg}, 0.76 \mathrm{mmol}$, 2-nitro17aethynilestradiol (fragment B) [260 mg, $0.76 \mathrm{mmol}$ ], Copper(II) chloride [105 mg, 0.78 $\mathrm{mmol}]$ and $5 \mathrm{ml}$ of methanol were stirred at room temperature for $72 \mathrm{~h}$. Then, the solvent was evaporated under reduced pressure and following the product was purified via crystallization using the methanol:hexane:water (4:2:1) system; yielding $52 \%$ of product; m.p. $218-220^{\circ} \mathrm{C}$; IR $\left(V_{\max }, \mathrm{cm}^{-1}\right) 3402,3312,1602$ and 1542: ${ }^{1} \mathrm{H}$ NMR $\left(300 \mathrm{MHz}, \mathrm{CDCl}_{3}-d\right) \delta_{\mathrm{H}}: 0.72(\mathrm{~s}, 3 \mathrm{H})$, 1.12-1.90 (m, 12H), $2.74(\mathrm{~s}, 3 \mathrm{H}), 2.77-2.90(\mathrm{~m}, 3 \mathrm{H}), 6.12-6.26(\mathrm{~m}, 2 \mathrm{H}), 6.48$ (broad, 3H), 6.60 $(\mathrm{m}, 1 \mathrm{H}), 6.66(\mathrm{~m}, 1 \mathrm{H}), 6.80-7.26(\mathrm{~m}, 3 \mathrm{H}), 7.82(\mathrm{~m}, 1 \mathrm{H}) \mathrm{ppm} .{ }^{13} \mathrm{C} \mathrm{NMR}\left(300 \mathrm{~Hz}, \mathrm{CDCl}_{3}\right) \delta_{\mathrm{C}}$ : 15.30, 23.76, 26.25, 27.86, 29.82, 30.26, 33.04, 33.14, 40.70, 42.60, 44.98, 50.88, 79.56, $112.54,114.04,116.00,119.55,123.54,126.57,128.44,128.60,132.33,132.90,135.66$, 138.50, 142.00, 145.08, 146.06, 148.46 ppm. EI-MS m/z: 472.23. Anal. Calcd. for $\mathrm{C}_{29} \mathrm{H}_{32} \mathrm{~N}_{2} \mathrm{O}_{4}$. C, 73.70; H, 6.83; N, 5.93; O, 13.54. Found: C, 73.68; H, 6.80. (15S,16S)-16-methyl-15-[4-[3-(methylamino)phenyl]cyclobuta-1,3-dien-1-yl]-5oxapentacyclo[9.7.0.02,8.04,6.012,16]octadeca-2(8),3,6-trien-15-ol (5).

In a round bottom flask $(10 \mathrm{ml})$, compound 2 [100 $\mathrm{mg}, 0.76 \mathrm{mmol}]$, oxirenol-steroid derivative (fragment C) [225 mg, $0.76 \mathrm{mmol}$ ], Copper(II) chloride [105 mg, $0.78 \mathrm{mmol}]$ and 5 $\mathrm{ml}$ of methanol were stirred at room temperature for $72 \mathrm{~h}$. Then, the solvent was evaporated under reduced pressure and following the product was purified via crystallization using the methanol:water (4:1) system; yielding $66 \%$ of product; m.p. $170-172{ }^{\circ} \mathrm{C}$; IR ( $\left.V_{\max }, \mathrm{cm}^{-1}\right) 3400$, 3310, 1622 and 1222: ${ }^{1} \mathrm{H}$ NMR (300 MHz, $\left.\mathrm{CDCl}_{3}-d\right) \delta \mathrm{H}: 0.72(\mathrm{~s}, 3 \mathrm{H}), 1.12-244(\mathrm{~m}, 13 \mathrm{H}), 2.74$ (s, 3H), 2.77-2.80 (m, 2H), 4.92 (broad, 2H), 6.12-6.26 (m, 2H), 6.30-6.32 (m, 2H), 6.60-7.26 $(\mathrm{m}, 4 \mathrm{H}) \mathrm{ppm} .{ }^{13} \mathrm{C} \mathrm{NMR}\left(300 \mathrm{~Hz}, \mathrm{CDCl}_{3}\right) \delta_{\mathrm{C}}: 15.30,23.76,26.25,27.86,29.82,30.26,33.04$, 33.14 , 40.70, 42.60, 45.40, 50.88, 79.56, 108.84, 108.90, 112.56, 116.00, 119.55, 126.57, $128.44,128.60,130.33,134.90,135.66,138.50,142.00,146.08,147.40,147.64$ ppm. EI-MS m/z: 425.23. Anal. Calcd. for $\mathrm{C}_{2} \mathrm{H}_{31} \mathrm{NO}_{2}$. C, 81.85; H, 7.34; N, 3.29; O, 7.52. Found: C, 81.82; H, 7.32.

(13S,17S)-13-methyl-17-[4-[3-(methylamino)phenyl]cyclobuta-1,3-dien-1-yl]-

7,8,9,11,12,14,15,16-octahydro-6H-cyclopenta[a] phenanthrene-3,17-dicarbaldehyde (6).

In a round bottom flask $(10 \mathrm{ml})$, compound 2 [100 $\mathrm{mg}, 0.76 \mathrm{mmol}$, $17 \alpha$-ethynylsteroid-3,17-dicarbaldehyde (fragment D) [245 mg, $0.76 \mathrm{mmol}$ ], Copper(II) chloride [105 mg, $0.78 \mathrm{mmol}]$ and $5 \mathrm{ml}$ of methanol were stirred at room temperature for $72 \mathrm{~h}$. Then, the solvent was evaporated under reduced pressure and following the product was purified via crystallization using the methanol:water (3:1) system; yielding $65 \%$ of product; m.p. 144-146 ${ }^{\circ} \mathrm{C}$; IR $\left(V_{\max }, \mathrm{cm}^{-1}\right) 3312,1720$ and 1602: ${ }^{1} \mathrm{H}$ NMR $\left(300 \mathrm{MHz}, \mathrm{CDCl}_{3}-d\right) \delta_{\mathrm{H}}: 1.10(\mathrm{~s}, 3 \mathrm{H}), 1.12-$ $2.58(\mathrm{~m}, 13 \mathrm{H}), 2.74(\mathrm{~s}, 3 \mathrm{H}), 2.82-2.86(\mathrm{~m}, 2 \mathrm{H}), 5.96$ (broad, $1 \mathrm{H}), 6.06-6.08(\mathrm{~m}, 2 \mathrm{H}), 6.60-6.80$ (m, 2H), 7.16 (m, 1H), 7.18-7.40 (m, 2H), 7.48-7.60 (m, 2H), $10.02(\mathrm{~s}, 1 \mathrm{H}), 10.06(\mathrm{~s}, 1 \mathrm{H}) \mathrm{ppm}$. ${ }^{13} \mathrm{C} \mathrm{NMR}\left(300 \mathrm{~Hz}, \mathrm{CDCl}_{3}\right) \delta_{\mathrm{C}}: 17.80,24.24,24.55,27.26,27.76,29.62,30.26,35.74,36.34$, 40.90, 44.60, 52.78, 61.78, 111.92, 116.00, 118.90, 124.75, 125.40, 126.10, 128.44, 129.85, 132.13, 135.16, 135.66, 135.90, 136.70, 143.50, 147.44, 150.92, 192.12, 195.32 ppm. EI-MS m/z: 451.25. Anal. Calcd. for $\mathrm{C}_{31} \mathrm{H}_{33} \mathrm{NO}_{2}$. C, 82.45; H, 7.37; N, 3.10; O, 7.09. Found: C, 82.42; $\mathrm{H}, 7.34$. 
(13S,17S)-13-methyl-17-[4-[3-(methylamino)phenyl]cyclobuta-1,3-dien-1-yl]-2-nitro7,8,9,11,12,14,15,16-octahydro-6H-cyclo-penta[a]phenanthrene-3,17-dicarbaldehyde (7).

In a round bottom flask $(10 \mathrm{ml})$, compound 2 [100 $\mathrm{mg}, 0.76 \mathrm{mmol}$, 17-ethynyl-2-nitrosteroid-3,17-dicarbaldehyde (fragment E) [265 mg, $0.76 \mathrm{mmol}$ ], Copper(II) chloride [105 mg, $0.78 \mathrm{mmol}$ ] and $5 \mathrm{ml}$ of methanol were stirred at room temperature for $72 \mathrm{~h}$. Then, the solvent was evaporated under reduced pressure and following the product was purified via crystallization using the methanol:water (4:1) system; yielding $56 \%$ of product; m.p. 188-190 ${ }^{\circ} \mathrm{C}$; IR $\left(V_{\max }, \mathrm{cm}^{-1}\right) 3312,1722,1600$ and 1540: ${ }^{1} \mathrm{H}$ NMR $\left(300 \mathrm{MHz}, \mathrm{CDCl}_{3}-d\right) \delta_{\mathrm{H}}: 1.10$ (s, $3 \mathrm{H}), 1.12-2.58(\mathrm{~m}, 12 \mathrm{H}), 2.74(\mathrm{~s}, 3 \mathrm{H}), 2.82-2.92(\mathrm{~m}, 3 \mathrm{H}), 5.96$ (broad, $1 \mathrm{H}), 6.06-6.08(\mathrm{~m}, 2 \mathrm{H})$, 6.60-7.40 (m, 4H), 7.80-7.92 (m, 2H), $10.06(\mathrm{~s}, 1 \mathrm{H}), 10.06(\mathrm{~s}, 1 \mathrm{H}), 10.80(\mathrm{~s}, 1 \mathrm{H}) \mathrm{ppm} .{ }^{13} \mathrm{C}$ $\operatorname{NMR}\left(300 \mathrm{~Hz}, \mathrm{CDCl}_{3}\right) \delta_{\mathrm{C}}: 17.80,24.24,24.55,27.26,27.76,29.62,30.26,35.74,36.34,40.90$, $44.98,52.78,61.78,111.92,116.00,118.90,122.72,126.22$, 126.50, 128.44, 129.85, 132.13, 135.16, 135.66, 143.50, 145.52, 147.44, 151.74, 152.74, 194.22, 195.32 ppm. EI-MS m/z: 496.23. Anal. Calcd. for $\mathrm{C}_{31} \mathrm{H}_{32} \mathrm{~N}_{2} \mathrm{O}_{4}$. C, 74.98; H, 6.50; N, 5.64; O, 12.89. Found: C, 74.96; $\mathrm{H}, 5.63$.

\subsection{Ligand-protein interaction.}

The interaction of the steroid derivatives with the COVID-19 surface was evaluated using 6LU7 protein as a theoretical model [20]. Furthermore, to calculate binding energy involved in the interaction of the steroid derivative and 6LU7-protein surface, either chloroquine, remdesivir, and favipiravir as controls were used on a docking Server software [21].

\subsection{Pharmacokinetics Parameter.}

To evaluate some pharmacokinetic factors involved in the chemical structure of the steroid derivatives, the SwissADME software was used [22].

\section{Results and Discussion}

Several drugs have been developed for the treatment of coronavirus disease (COVID19) using some reagents which are dangerous and require special conditions [13-17]. Furthermore, the interaction with COVID-19 is very confusing; perhaps, this phenomenon could be to different structure chemical of each compound. Analyzing these data, in this investigation, five cyclobuta-1,3-dien-1-yl-steroid derivatives were synthesized to evaluate their interaction with COVID-19 using several strategies as follows.

\subsection{Methylation reaction.}

There are studies for methylation of some compounds using several reagents such as Copper [23], Ruthenium [24], Iridium chloride [25], Cobalt [26], Manganese chloride [27], Palladium [28], Nikel [29] and others. In this research, the compound 3-Ethynyl-phenyl)methyl-amine (2) was prepared from 3-ethynylaniline and methanol in the presence of palladium on carbon in middle conditions (Figure 1).

The ${ }^{1} \mathrm{H}$ NMR spectrum of $\mathbf{2}$ showed several signals at $2.82 \mathrm{ppm}$ for alkyne group; at 2.82 ppm for methyl group; at 4.82 for the amino group; at 6.54-7.12 ppm for phenyl group. The ${ }^{13} \mathrm{C}$ NMR spectra display chemical shifts at $30.32 \mathrm{ppm}$ for methyl group; at 78.22 and 
84.00 for alkyne group; at $114.50-151.30 \mathrm{ppm}$ for phenyl group. Additionally, the mass spectrum from 2 showed a molecular ion $(\mathrm{m} / \mathrm{z}) 13.07$.

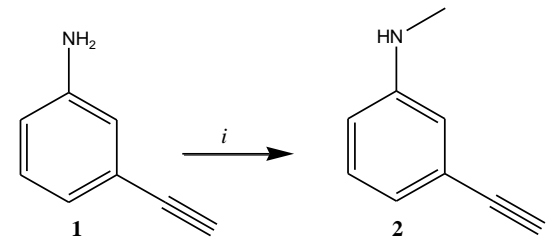

Figure 1. Synthesis of (3-Ethynyl-phenyl)-methyl-amine (2). Reagents and conditions: $i=3$-ethynylaniline, palladium on carbon, methanol, potassium hydroxide, reflux, $12 \mathrm{~h}$.

\subsection{Synthesis of cyclobuta-1,3-dien-1-yl-steroid derivatives.}

Several cyclobutadiene derivatives have been prepared using some reagents such as $\mathrm{PdCl}_{2}$, [30], cobalt chloride [31], 1,2-dibromoethane [32], Cupric chloride [33], ruthenium chloride [34], tetrakis(trimethylsilyl)cyclobutadienylcyclopentadienyl cobalt complex [35] and others. In this study, five cyclobutadiene-steroid derivatives were prepared (compound $\mathbf{3}$ to 7) from some steroid-analogs (A to E fragments) and compound 2 in the presence of Copper(II) chloride (Figure 2). The ${ }^{1} \mathrm{H}$ NMR spectrum of $\mathbf{3}$ showed several signals at $0.72 \mathrm{ppm}$ for methyl groups bound to steroid nucleus; at 1.12-2.50, 2.77-2.80, 6.72-6.76 and 7.20 ppm for steroid moiety; at 2.74 for methyl bound to the amino group; at $6.26 \mathrm{ppm}$ for both hydroxyl and amino groups; at 6.12 and $6.28 \mathrm{ppm}$ for cyclobutadiene ring; at 6.60, 6.80-7.16 and 7.26 ppm for phenyl group. The ${ }^{13} \mathrm{C}$ NMR spectra display chemical shifts at 15.12 for methyl group linked to steroid nucleus; at $30.28 \mathrm{ppm}$ for methyl bound to the amino group; at 23.76-30.26, 33.0479.56, 113.64-115.96, 126.76, 131.92, 138.20 and $156.02 \mathrm{ppm}$ for steroid moiety; at 112.54, $116.00-119.55,128.44,135.66$ and $146.06 \mathrm{ppm}$ for phenyl group; at 126.57, 128.60 and 138.50-142.00 for cyclobutadiene ring. Finally, the mass spectrum from $\mathbf{3}$ showed a molecular ion $(\mathrm{m} / \mathrm{z}) 427,25$.

On the other hand, other data display several signals involved in the ${ }^{1} \mathrm{H}$ NMR spectrum for 4 at $0.72 \mathrm{ppm}$ for methyl group bound to steroid nucleus; at $2.74 \mathrm{ppm}$ for methyl group bound to the amino group; at 1.2-1.90, 2.77-2.90, 6.66 and $7.82 \mathrm{ppm}$ for steroid moiety; at 6.12-6.26 ppm for cyclobutadiene ring; at 6.48 for both amino and hydroxyl groups; at 6.60 and 6.80-7.26 ppm for phenyl group. In addition, the ${ }^{13} \mathrm{C}$ NMR spectra display chemical shifts at $12.42-15.30 \mathrm{ppm}$ for methyl groups linked to steroid nucleus; at $30.26 \mathrm{ppm}$ for methyl bound to the amino group; at 23.76-29.82, 33.04-79.56, 114.04, 123.54, 132.33-132.90, 145.08 and 148.46 ppm for steroid moiety; at 112.54, 116.00-119.55, 128.44, 135.66 and 146.06 ppm for phenyl group; at 126.57, 128.60 and 138.50142 .00 ppm for cyclobutadiene ring. In addition, the mass spectrum from 4 showed a molecular ion $(\mathrm{m} / \mathrm{z}) 472.23$.

In addition, the ${ }^{1} \mathrm{H}$ NMR spectrum of $\mathbf{5}$ showed several signals at $0.72 \mathrm{ppm}$ for methyl group bound to steroid nucleus; at $2.74 \mathrm{ppm}$ for methyl group bound to the amino group; at 1.22-2.44, 2.77-2.80 and 6.30-6.32 ppm for steroid moiety; at 6.80-7.26 ppm for phenyl group; at $4.92 \mathrm{ppm}$ for both hydroxyl and amino groups; at $6.12-6.26 \mathrm{ppm}$ for cyclobutadiene ring. The ${ }^{13} \mathrm{C}$ NMR spectra display chemical shifts at $15.30 \mathrm{ppm}$ for methyl group linked to steroid nucleus; at $30.26 \mathrm{ppm}$ for methyl bound to the amino group; at 23.76-29.86, 33.04-108.90, 130.33-134.0 and 147.40-147.60 ppm for steroid moiety; at 112.56-119.55, 128.44, 135.66 and $146.08 \mathrm{ppm}$ for phenyl group; at 126.57, 128.60 and 138.50-142.00 ppm for cyclobutadiene ring. Additionally, the mass spectrum from 5 showed a molecular ion (m/z) 425.23. 

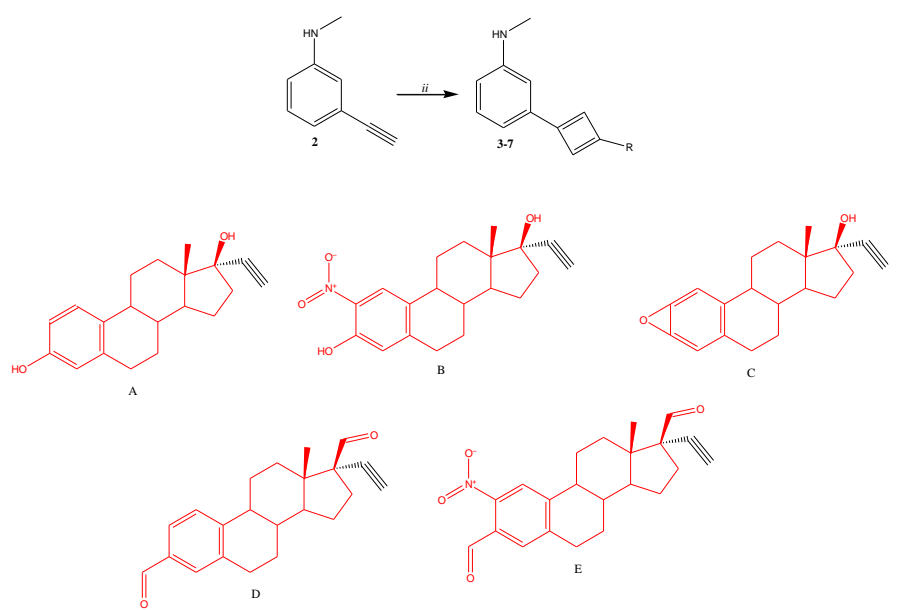

Figure 2. Preparation of cyclobutadiene-steroid derivatives (3-7). reagents and conditions: $i i=$ Copper(II) chloride, methanol, room temperature, $12 \mathrm{~h}$. Fragments; A = 17 $\alpha$-ethynilestradiol; B $=2$-nitro-

17aethynilestradiol; $\mathrm{C}=$ oxirenol-steroid derivative; $\mathrm{D}=17 \alpha$-ethynyl-steroid-3,17-dicarbaldehyde; $\mathrm{E}=17$ ethynyl-2-nitro-steroid-3,17-dicarbaldehyde.

Other data involved in the ${ }^{1} \mathrm{H}$ NMR spectrum of $\mathbf{6}$ showed several signals at $1.10 \mathrm{ppm}$ for methyl group bound to steroid nucleus; at $2.74 \mathrm{ppm}$ for methyl group bound to the amino group; at 1.22-2.58, 2.82-2.86, 7.16 and 7.48-7.60 ppm for steroid moiety; at $5.96 \mathrm{ppm}$ for the amino group; at 6.06-6.08 ppm for cyclobutadiene ring; at 6.60-6.80 and 7.18-7.40 ppm for phenyl group; at 10.02 and $10.06 \mathrm{ppm}$ for aldehyde groups. The ${ }^{13} \mathrm{C}$ NMR spectra display chemical shifts at $17.80 \mathrm{ppm}$ for methyl group linked to steroid nucleus; at $30.26 \mathrm{ppm}$ for methyl bound to the amino group; at 24.24-29.62, 35.74-61.78, 124.75-128.10, 135.90-136.70 and $150.92 \mathrm{ppm}$ for steroid moiety; at 11.92-118.90, 129.85, 135.66 and $147.44 \mathrm{ppm}$ for phenyl group; at 128.44, 132.13-135.16 and $143.50 \mathrm{ppm}$ for cyclobutadiene ring; at 192.12-195.32 ppm for aldehyde groups. Additionally, the mass spectrum from $\mathbf{6}$ showed a molecular ion $(\mathrm{m} / \mathrm{z}) 451.25$.

Finally, the ${ }^{1} \mathrm{H}$ NMR spectrum for 7 display several signals at $1.10 \mathrm{ppm}$ for methyl group bound to steroid nucleus; at $2.74 \mathrm{ppm}$ for methyl group bound to the amino group; at 1.22-2.50, 2.82-2.86 and 7.80-7.92 ppm for steroid moiety; at $5.96 \mathrm{ppm}$ for the amino group; at 6.06-6.08 ppm for cyclobutadiene ring; at 6.60-7.40 ppm for phenyl group; at 10.02 and $10.80 \mathrm{ppm}$ for aldehyde groups. The ${ }^{13} \mathrm{C}$ NMR spectra display chemical shifts at $17.80 \mathrm{ppm}$ for methyl group linked to steroid nucleus; at $30.26 \mathrm{ppm}$ for methyl bound to the amino group; at 24.24-29.62, 35.74-61.78, 122.72-126.50, 145.52 and 151.74-152.74 ppm for steroid moiety; at 11.92-118.90, 129.85 and 135.66 and 144.44 ppm for phenyl group; at 128.44, 132.13135.16 , and143.50 ppm for cyclobutadiene ring; at 194.22-195.32 ppm for aldehyde groups. Besides, the mass spectrum from 7 showed a molecular ion $(\mathrm{m} / \mathrm{z}) 491.23$.

\subsection{Ligand-protein interaction.}

For several years, some techniques were used to analyze the coupling of biomolecules with some drugs; These techniques involve the flexible coupling of ligands on the surface of some either protein or enzyme. Furthermore, these studies involve the evaluation of the free binding energies and the solvation energies involved between the ligand-biomolecule interaction [36-41]. In this way, in this investigation a theoretical ass was carried out to analyze the interaction of steroid derivatives with the 6LU7-protein surface. 


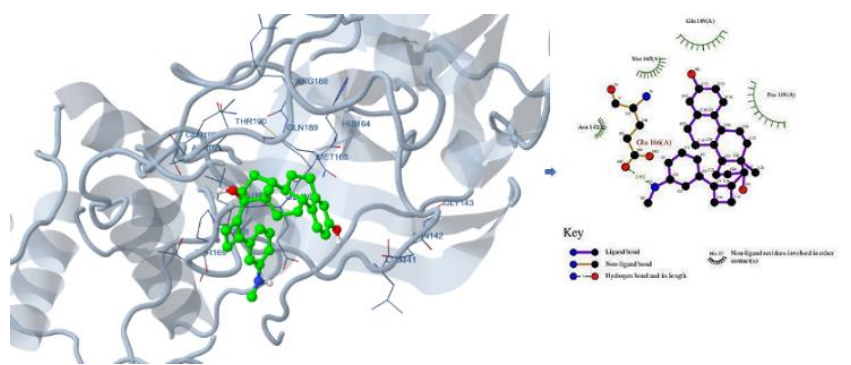

Figure 3. Interaction of compound 3 with 6LU7-protein surface using docking server.

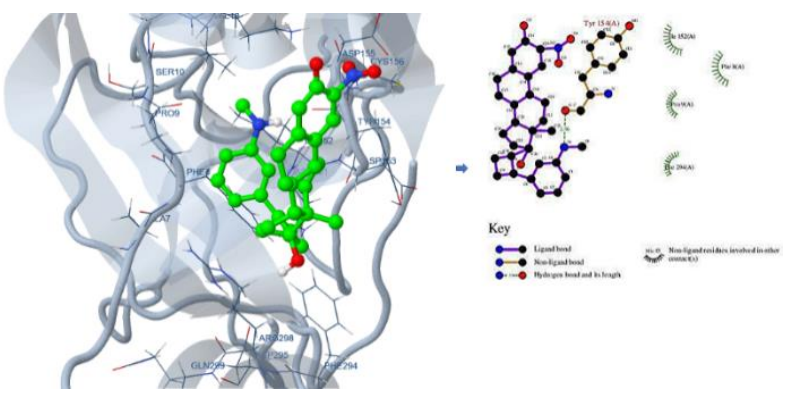

Figure 4. Binding of compound 4 with 6LU7-protein surface using docking server.

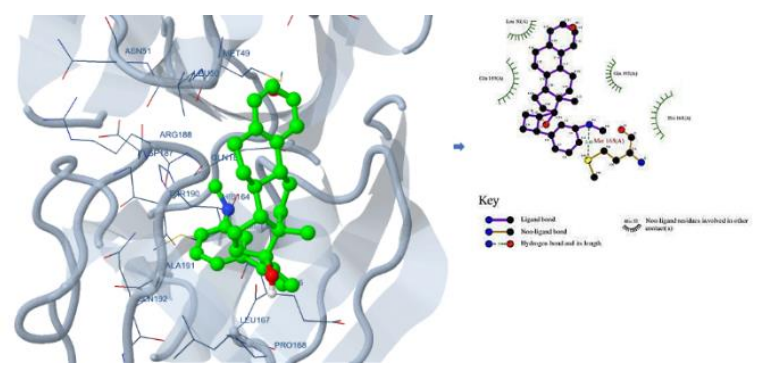

Figure 5. Interaction of compound 5 with 6LU7-protein surface using docking server.

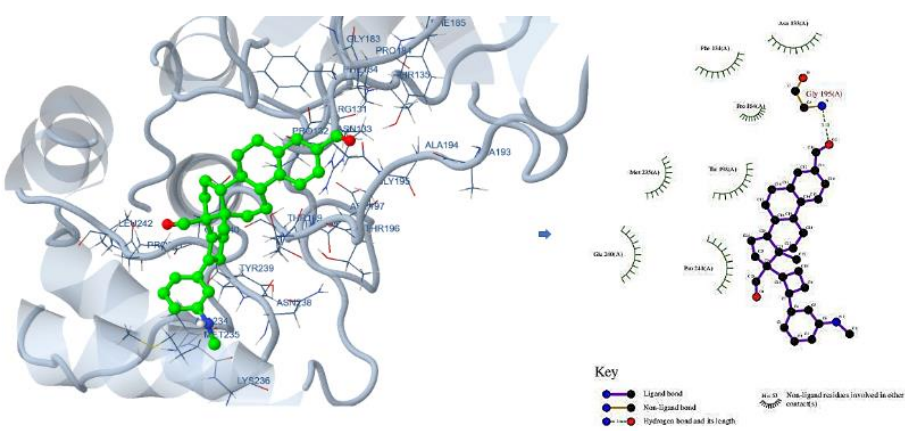

Figure 6. Binding of compound 6 with 6LU7-protein surface using docking server.

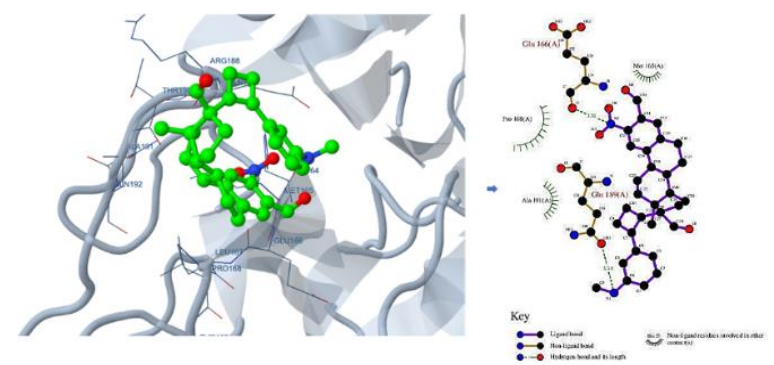

Figure 7. Interaction of compound 7 with 6LU7-protein surface using docking server.

The results (Figures 3-7; Table 1) showed that there are different amino acid residues involved in the binding of the steroid derivatives with 6LU7 protein surface; however, the inhibition constant (Ki) for compound 6 was lower compared with either compounds 3-5, 7 
and the controls (favipiravir, chloroquine, and remdesivir). Furthermore, compound $\mathbf{5}$ also showed a good theoretical interaction with 6LU7-protein surface (Ki, 4.73; Table 2).

Table 1. Interaction of either steroid-derivatives and controls (chloroquine, remdesivir, and favipiravir) with 6ก̃U7-protein surface.

\begin{tabular}{l|l|l|l|l|l|l|l}
\multicolumn{7}{c}{ I-------------------------------- } \\
\hline Favipiravir & Chloroquine & Remdesivir & 1 & 2 & 3 & 4 & 5 \\
\hline Met17 & His164 & Glu166 & Asn142 & Phe8 & Leu50 & Asn133 & Met165 \\
Gln19 & Met165 & Leu167 & Met165 & Pro9 & Met165 & Phe134 & Glu166 \\
Gln69 & Glu166 & Pro168 & Glu166 & Ile152 & Pro168 & Pro184 & Pro168 \\
Asn119 & Pro168 & Gln189 & Pro168 & Tyr154 & Gln189 & Gly195 & Gln189 \\
Gly120 & Gln189 & Ala191 & Gln189 & Phe294 & Gln192 & Thr198 & Ala191 \\
Ser121 & & Ala193 & & & & Met235 & \\
& & & & & & Glu240 & \\
& & & & & & Pro241 &
\end{tabular}

Table 2. Thermodynamic parameters involved in the binding of either steroid-derivatives and controls (chloroquine, remdesivir and favipiravir) with 6ÑU7-protein surface.

\begin{tabular}{l|l|l|l|l|l|l} 
Compound & $\begin{array}{l}\text { Est. Free } \\
\text { energy of } \\
\text { Binding }\end{array}$ & $\begin{array}{l}\text { Est. } \\
\text { Inhibition } \\
\text { Constant (Ki) }\end{array}$ & $\begin{array}{l}\text { vdW + H-bond } \\
+ \text { Energy }\end{array}$ & $\begin{array}{l}\text { Electrostati } \\
\text { desolv Energy }\end{array}$ & $\begin{array}{l}\text { Total Interm. } \\
\text { Energy }\end{array}$ & $\begin{array}{l}\text { Interact } \\
\text { Surface }\end{array}$ \\
\hline Chloroquine & -3.99 & 1.20 & -4.54 & -2.03 & -6.56 & 495.65 \\
\hline Remdesivir & -2.45 & 15.90 & -6.09 & -0.38 & -6.48 & 643.33 \\
\hline Fivipiravir & -3.73 & 1.83 & -3.97 & -0.06 & -4.03 & 338.65 \\
\hline 3 & -6.56 & 15.43 & -8.04 & -0.04 & -8.09 & 716.06 \\
\hline 4 & -5.11 & 93.11 & -6.42 & 0.10 & -6.32 & 611.75 \\
\hline 5 & -7.27 & 4.73 & -7.80 & 0.00 & -7.79 & 726.52 \\
\hline 6 & -4.08 & 1.03 & -4.81 & -0.11 & -4.92 & 636.16 \\
\hline 7 & -5.58 & 81.02 & -5.98 & -0.04 & -6.02 & 595.67
\end{tabular}

\subsection{Pharmacokinetic evaluation.}

Several studies have reported the evaluation of some pharmacokinetic parameters of different drugs using theoretical models such as PKQuest [40], PharmPK [41] Gitub [42], SwissADME [43]. In this way, in this research, some pharmacokinetic parameters possibly involved in the steroid derivatives were evaluated using the SwissADME software. The results (Table 3) indicate that these compounds could have different gastrointestinal absorption and, consequently, their metabolism could involve different types of CYP enzymes (Cytochrome P450 system).

Table 3. The pharmacokinetics properties of the Fluoro-2,4dioxaspiro[bicyclo[3.3.1]indene derivative. The values determine using the SwissADME software.

\begin{tabular}{|c|c|c|c|c|c|}
\hline Parameter & 3 & 4 & 5 & 6 & 7 \\
\hline GI absortion & high & Low & high & high & Low \\
\hline BBB permenat & No & No & No & No & No \\
\hline P-gp substrate & No & Yes & No & No & Yes \\
\hline CYP1A2 inhibitor & No & No & $\mathrm{No}$ & Yes & No \\
\hline CYP2C19 inhibitor & $\mathrm{No}$ & No & $\mathrm{No}$ & No & No \\
\hline CYP2C9 inhibitor & $\mathrm{No}$ & Yes & No & Yes & Yes \\
\hline CYP2D6 inhibitor & No & No & No & Yes & $\mathrm{No}$ \\
\hline CYP3A4 inhibitor & No & Yes & Yes & Yes & Yes \\
\hline $\operatorname{LogK}_{p}(\mathrm{~cm} / \mathrm{s})$ & -5.06 & -4.97 & -5.69 & -4.77 & -5.17 \\
\hline
\end{tabular}

\section{Conclusions}

In this investigation, the synthesis of five cyclobuta-1,3-dien-1-yl-steroid derivatives using several chemical strategies is reported. Furthermore, theoretical analysis of the interaction between steroid derivatives showed a higher affinity of compounds $\mathbf{5}$ and $\mathbf{6}$ by the 
6LU7-protein surface. All these data suggest that both compounds 5 and $\mathbf{6}$ could be good candidates as COVID-19 inhibitors.

\section{Funding}

This research received no external funding.

\section{Acknowledgments}

To Benjamin Valverde and Raquel Anzurez, for your unconditional support on this manuscript.

\section{Conflicts of Interest}

The authors declare no conflict of interest.

\section{References}

1. Zhang, J.; Zhou, L.; Yang, Y.; Peng, W.; Wang, W.; Chen, X. Therapeutic and triage strategies for 2019 novel coronavirus disease in fever clinics. The Lancet Respiratory Medicine 2020, 8, e11-e12, https://doi.org/10.1016/S2213-2600(20)30071-0.

2. Perelló, R.; Moreno, A.; Camps, M.; Cervera, C.; Linares, L.; Pumarola, T.; Marcos, M. Implicación de los virus respiratorios en la neumonía adquirida en la comunidad en pacientes infectados por el virus de la inmunodeficiencia humana. Enfermedades Infecciosas y Microbiología Clínica 2008, 26, 85-87, https://doi.org/10.1157/13115543.

3. Fong-Ponce, B. Neumonía adquirida en la comunidad: Identificando las comorbilidades como factores de riesgo. Karger Kompass Neumología 2020, 2, 24-25, https://doi.org/10.1159/000504867.

4. Matus, C.; Oyarzún, G. Impacto Del Material Particulado aéreo (MP 2, 5) sobre las hospitalizaciones por enfermedades respiratorias en niños: estudio caso-control alterno. Revista chilena de pediatría 2019, 90.2.

5. Galván, J.; Rajas, O.; Aspa, J. Revisión sobre las infecciones no bacterianas del aparato respiratorio: neumonías víricas. Archivos de Bronconeumología 2015, 51, 590-597, https://doi.org/10.1016/j.arbres.2015.02.015.

6. Tirado, M.; Silva P. Perfil epidemiológico de infecciones respiratorias agudas en adultos hospitalizados. Mediciencias UTA 3.3 2019, 3, 112-119, https://doi.org/10.31243/mdc.uta.v3i3.196.2019.

7. Lai, C.; Liu, Y.; Wang, C.; Wang, Y.; Hsueh, S.; Yen, M.; Hsueh, P. Asymptomatic carrier state, acute respiratory disease, and pneumonia due to severe acute respiratory syndrome coronavirus 2 (SARSCoV-2): Facts and myths. Journal of Microbiology, Immunology and Infection 2020, 53, 404-412, https://doi.org/10.1016/j.jmii.2020.02.012.

8. Chen, G.; Wu, D.; Guo, W.; Cao, Y.; Huang, D.; Wang, H.; Wang, T.; Zhang, X.; Chen, H.; Yu, H.; Zhang, X.; Zhang, M.; Wu, S.; Song, J.; Chen, T.; Han, M.; Li, S.; Luo, X.; Zhao, J.; Ning, Q. Clinical and immunological features of severe and moderate coronavirus disease 2019. The Journal of Clinical Investigation 2020, 130, 2620-2629, https://doi.org/10.1172/JCI137244.

9. Richardson, P.; Griffin, I.; Tucker, C.; Smith, D.; Oechsle, O.; Phelan, A.; Stebbing, J. Baricitinib as potential treatment for 2019-nCoV acute respiratory disease. Lancet (London, England) 2020, 395, e30, https://doi.org/10.1016/S0140-6736(20)30304-4.

10. Van Doremalen, N.; Bushmaker, T.; Morris, D.; Holbrook, M.; Gamble, A.; Williamson, B.; Lloyd-Smith, J. Aerosol and surface stability of SARS-CoV-2 as compared with SARS-CoV-1. New England Journal of Medicine, 2020, 382(16), 1564-1567.

11. Chen, L.; Liu, H.; Liu, W.; Liu, J.; Liu, K.; Shang, J.; Wei, S. Analysis of clinical features of 29 patients with 2019 novel coronavirus pneumonia. Chinese journal of tuberculosis and respiratory diseases 2020, 43, E005-E005.

12. Chen, N.; Zhou, M.; Dong, X.; Qu, J.; Gong, F.; Han, Y.; Yu, T. Epidemiological and clinical characteristics of 99 cases of 2019 novel coronavirus pneumonia in Wuhan, China: a descriptive study. The Lancet 2020, 395, 507-513, https://doi.org/10.1016/S0140-6736(20)30211-7.

13. Zhang, H.; Zhang, H.; Kemnitzer, W.; Tseng, B.; Cinatl, J.; Michaelis, M.; Cai, S. Design and synthesis of dipeptidyl glutaminyl fluoromethyl ketones as potent severe acute respiratory syndrome coronovirus (SARSCoV) inhibitors. Journal of Medicinal Chemistry 2006, 49, 1198-1201, https://doi.org/10.1021/jm0507678.

14. Zhang, L.; Lin, D.; Kusov, Y.; Nian, Y.; Ma, Q.; Wang, J.; DeWilde, A. $\alpha$-Ketoamides as broad-spectrum inhibitors of coronavirus and enterovirus replication: Structure-based design, synthesis, and activity assessment. Journal of Medicinal Chemistry 2020. 
15. Zhou, L.; Liu, Y.; Zhang, W.; Wei, P.; Huang, C.; Pei, J.; Yuan, Y.; Lai, L. Isatin Compounds as Noncovalent SARS Coronavirus 3C-like Protease Inhibitors. Journal of Medicinal Chemistry 2006, 49, 3440-3443, https://doi.org/10.1021/jm0602357

16. [Jacobs, J.; Grum-Tokars, V.; Zhou, Y.; Turlington, M.; Saldanha, S.A.; Chase, P.; Eggler, A.; Dawson, E.S.; Baez-Santos, Y.M.; Tomar, S.; Mielech, A.M.; Baker, S.C.; Lindsley, C.W.; Hodder, P.; Mesecar, A.; Stauffer, S.R. Discovery, Synthesis, And Structure-Based Optimization of a Series of N-(tert-Butyl)-2-(Narylamido)-2-(pyridin-3-yl) Acetamides (ML188) as Potent Noncovalent Small Molecule Inhibitors of the Severe Acute Respiratory Syndrome Coronavirus (SARS-CoV) 3CL Protease. Journal of Medicinal Chemistry 2013, 56, 534-546, https://doi.org/10.1021/jm301580n.

17. [Ghosh, A.K.; Takayama, J.; Rao, K.V.; Ratia, K.; Chaudhuri, R.; Mulhearn, D.C.; Lee, H.; Nichols, D.B.; Baliji, S.; Baker, S.C.; Johnson, M.E.; Mesecar, A.D. Severe Acute Respiratory Syndrome Coronavirus Papain-like Novel Protease Inhibitors: Design, Synthesis, Protein-Ligand X-ray Structure and Biological Evaluation. Journal of Medicinal Chemistry 2010, 53, 4968-4979, https://doi.org/10.1021/jm1004489.

18. Lauro, F.; Diaz-Cedillo, F.; Marcela, R.; Mateu-Armand, V.; Lopez-Ramos, M.; Raquel, E.;Yaritza, B.; Design and Synthesis of Two Methylthiosteroid-Oxirenol Derivatives: Theoretical Evaluation of Their Interaction with B1-Cannabinoid Receptor. Journal of Biochemical Technology 2019, 10.

19. Khaerunnisa, S.; Kurniawan, H.; Awaluddin, R.; Suhartati, S.; Soetjipto, S. Potential inhibitor of COVID19 main protease (Mpro) from several medicinal plant compounds by molecular docking study. Preprints 2020, 0226, 1-14.

20. Lauro, F.-V.; Francisco, D.-C.; Marcela, R.-N.; Virginia, M.-A.; Eduardo, P.G.; Maria, L.-R.; Lenin, H.-H.; Alondra, A.-J.; Jhair, C.-T. Preparation of a steroid-oxazole-1,2'-[1,3]oxazete] derivative: biological and theoretical evaluation of its interaction with a kinase protein (CK2). SN Applied Sciences 2019, 1, https://doi.org/10.1007/s42452-019-0378-7.

21. Daina, A.; Michielin, O.; Zoete, V. SwissADME: a free web tool to evaluate pharmacokinetics, drug-likeness and medicinal chemistry friendliness of small molecules. Scientific Reports 2017, 7, https://doi.org/10.1038/srep42717.

22. Xia, Q.; Liu, X.; Zhang, Y.; Chen, C.; Chen, W. Copper-Catalyzed N-Methylation of Amides and OMethylation of Carboxylic Acids by Using Peroxides as the Methylating Reagents. Organic Letters 2013, 15, 3326-3329, https://doi.org/10.1021/ol401362k.

23. Li, Y.; Xue, D.; Lu, W.; Wang, C.; Liu, Z.-T.; Xiao, J. DMF as Carbon Source: Rh-Catalyzed $\alpha$-Methylation of Ketones. Organic Letters 2014, 16, 66-69, https://doi.org/10.1021/o1403040g.

24. Tsukamoto, Y.; Itoh, S.; Kobayashi, M.; Obora, Y. Iridium-Catalyzed $\alpha$-Methylation of $\alpha$-Aryl Esters Using Methanol as the C1 Source. Organic Letters 2019, 21, 3299-3303, https://doi.org/10.1021/acs.orglett.9b01025.

25. Liu, Z.; Yang, Z.; Yu, X.; Zhang, H.; Yu, B.; Zhao, Y.; Liu, Z. Methylation of C(sp3)-H/C(sp2)-H Bonds with Methanol Catalyzed by Cobalt System. Organic Letters 2017, 19, 5228-5231, https://doi.org/10.1021/acs.orglett.7b02462.

26. Sato, T.; Yoshida, T.; Al Mamari, H.H.; Ilies, L.; Nakamura, E. Manganese-Catalyzed Directed Methylation of $\mathrm{C}(\mathrm{sp} 2)-\mathrm{H}$ Bonds at $25{ }^{\circ} \mathrm{C}$ with High Catalytic Turnover. Organic Letters 2017, 19, 5458-5461, https://doi.org/10.1021/acs.orglett.7b02778.

27. Haydl, A.M.; Hartwig, J.F. Palladium-Catalyzed Methylation of Aryl, Heteroaryl, and Vinyl Boronate Esters. Organic Letters 2019, 21, 1337-1341, https://doi.org/10.1021/acs.orglett.9b00025.

28. Liang, Z.; Xue, W.; Lin, K.; Gong, H. Nickel-Catalyzed Reductive Methylation of Alkyl Halides and Acid Chlorides with Methyl p-Tosylate. Organic Letters 2014, 16, 5620-5623, https://doi.org/10.1021/ol502682q.

29. Li, W.; Lang, M.; Wang, J. Access to Cyclobutadienes via an Organocatalytic Dienamine-IminiumAllenamine Cascade Approach. Organic Letters 2017, 19, 4564-4567, https://doi.org/10.1021/acs.orglett.7b02161.

30. Kimling, H.; Krebs, A. Synthesis of a cyclobutadiene stabilized by steric effects. Angewandte Chemie International Edition in English, 1972, 11(10), 932-933. https://doi.org/10.1002/anie.197209321

31. Sekiguchi, A.; Tanaka, M.; Matsuo, T.; Watanabe, H. From a Cyclobutadiene Dianion to a Cyclobutadiene: Synthesis and Structural Characterization of Tetrasilyl-Substituted Cyclobutadiene. Angewandte Chemie International Edition 2001, 40, 1675-1677, https://doi.org/10.1002/1521-3773(20010504)40:9<1675::AIDANIE16750>3.0.CO;2-G.

32. Bunz, U.H.F.; Roidl, G.; Altmann, M.; Enkelmann, V.; Shimizu, K.D. Synthesis and Structural Characterization of Novel Organometallic Dehydroannulenes with Fused CpCo-Cyclobutadiene and Ferrocene Units Including a Cyclic Fullerenyne Segment. Journal of the American Chemical Society 1999, 121, 10719-10726, https://doi.org/10.1021/ja992262a.

33. Yamamoto, Y.; Arakawa, T.; Itoh, K. Synthesis of Naphthoquinone-Fused Cyclobutadiene Ruthenium Complexes. Organometallics 2004, 23, 3610-3614, https://doi.org/10.1021/om049732g.

34. Sekiguchi, A.; Matsuo, T.; Tanaka, M.; Watanabe, H.; Nakamoto, M. Tetrasilyl-substituted cyclobutadiene dianion dilithium salt: synthesis and structure. Russian Chemical Bulletin 2004, 53, 1109-1115, https://doi.org/10.1023/B:RUCB.0000041308.25889.77. 
35. Lybrand, T.P. Ligand-protein docking and rational drug design. Current Opinion in Structural Biology 1995, 5, 224-228, https://doi.org/10.1016/0959-440X(95)80080-8.

36. Li, J.; Fu, A.; Zhang, L. An Overview of Scoring Functions Used for Protein-Ligand Interactions in Molecular Docking. Interdisciplinary Sciences: Computational Life Sciences 2019, 11, 320-328, https://doi.org/doi:10.1007/s12539-019-00327-w.

37. García-Nieto, J.; López-Camacho, E.; García-Godoy, M.J.; Nebro, A.J.; Aldana-Montes, J.F. Multiobjective ligand-protein docking with particle swarm optimizers. Swarm and Evolutionary Computation 2019, 44, 439-452, https://doi.org/10.1016/j.swevo.2018.05.007.

38. Nguyen, D.D.; Wei, G.-W. AGL-Score: Algebraic Graph Learning Score for Protein-Ligand Binding Scoring, Ranking, Docking, and Screening. Journal of Chemical Information and Modeling 2019, 59, 32913304, https://doi.org/10.1021/acs.jcim.9b00334.

39. Evangelista Falcon, W.; Ellingson, S.R.; Smith, J.C.; Baudry, J. Ensemble Docking in Drug Discovery: How Many Protein Configurations from Molecular Dynamics Simulations are Needed To Reproduce Known Ligand Binding? The Journal of Physical Chemistry B 2019, 123, 5189-5195,. https://doi.org/10.1021/acs.jpcb.8b11491.

40. Levitt, D. PKQuest_Java: free, interactive physiologically based pharmacokinetic software package and tutorial. BMC Research Notes 2009, 2, 1-6, https://doi.org/10.1186/1756-0500-2-158.

41. Ishaku, S.; Bakare, M.; Musa, A.; Yakasai, I.; Garba, M.; Adzu, B. Evaluating the effect of artesunate on the pharmacokinetics of gliclazide in diabetic subjects. International Journal of Biological and Chemical Sciences 2019, 13, 2104-2111.

42. Guerra, R.P.; Carvalho, A.M.; Mateus, P. Model selection for clustering of pharmacokinetic responses. Computer Methods and Programs in Biomedicine 2018, 162, 11-18, https://doi.org/10.1016/j.cmpb.2018.05.002.

43. Briasoulis, E.; Pavlidis, N.; Terret, C.; Bauer, J.; Fiedler, W.; Schöffski, P.; Raoul, J.L.; Hess, D.; Selvais, R.; Lacombe, D.; Bachmann, P.; Fumoleau, P. Glufosfamide administered using a 1-hour infusion given as first-line treatment for advanced pancreatic cancer. A phase II trial of the EORTC-new drug development group. European Journal of Cancer 2003, 39, 2334-2340, https://doi.org/10.1016/S0959-8049(03)00629-4.

44. Rosas-Nexticapa Marcela Figueroa-Valverde Lauro, Díaz-Cedillo Francisco , López-Ramos Maria, MateuArmad Maria Virginia, Garcimarrero E. Alejandara, Cauich-Carrillo Regina. Design and Two New IndolSteroid Derivatives to Evaluate their Theoretical Activity Against Protein Kinase 2 (CK2) Protein. Biointerface Research in Applied Chemistry. 2020, 10(6), 6810-6820. https://doi.org/10.33263/BRIAC106.68106820 